Advertisement

Springer Link

Computational Statistics and Mathematical Modeling Methods in Intelligent Systems

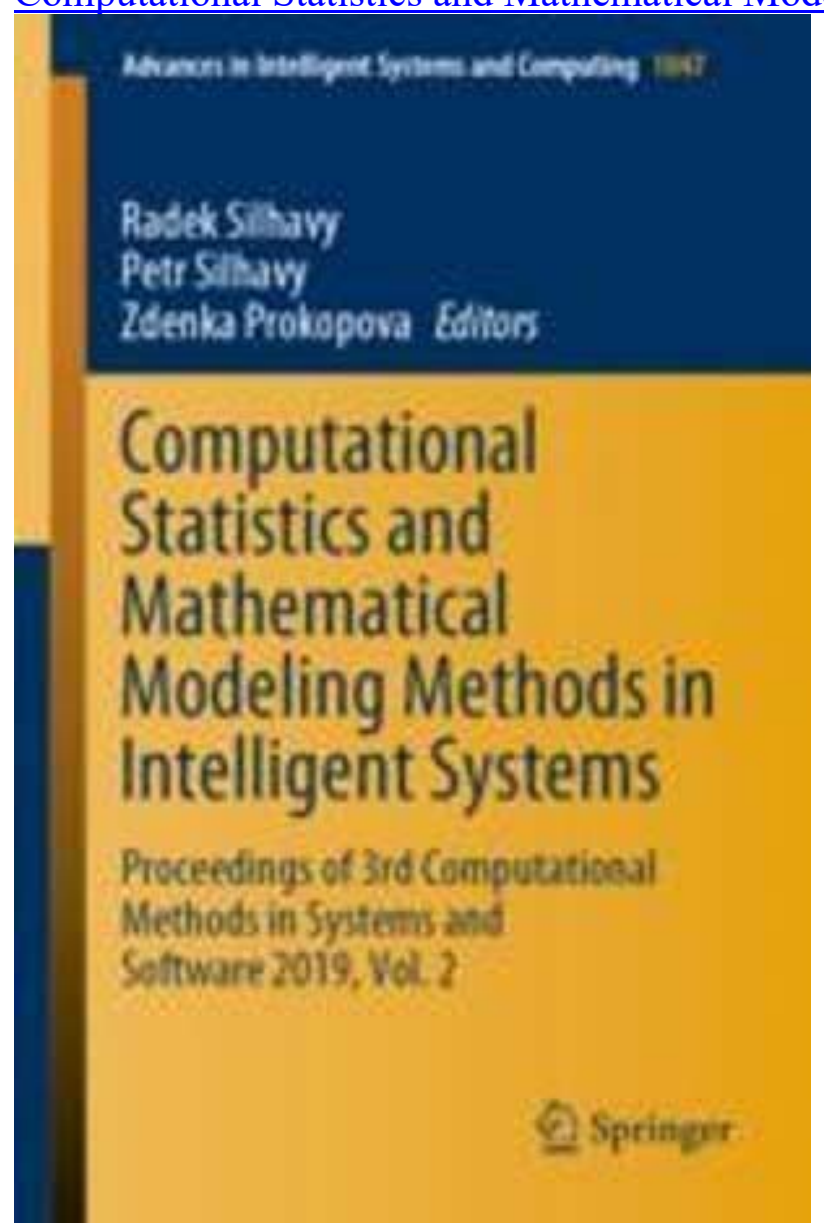

Proceedings of the Computational Methods in Systems and Software

CoMeSySo 2019 2019: Computational Statistics and Mathematical Modeling Methods in $\underline{\text { Intelligent Systems pp 125-135 | Cite as }}$

\title{
An Improved Location Model for the Collection of Sorted Solid Waste in Densely Populated Urban Centres
}

- Authors

- $\quad$ Authors and affiliations

- Olawale J. Adeleke 
- David O. Olukanni

- Micheal O. Olusanya

- Olawale J. Adeleke

o 1

Email author

- David O. Olukanni

o 2

- Micheal O. Olusanya

o 3

1. 1.Department of Mathematics, College of Science and TechnologyCovenant UniversityOtaNigeria

2. 2.Department of Civil Engineering, College of EngineeringCovenant UniversityOtaNigeria

3. 3.Department of Information Technology, Faculty of Accounting and InformaticsDurban University of TechnologyDurbanRepublic of South Africa

Conference paper

First Online: 20 September 2019

- 178 Downloads

Part of the Advances in Intelligent Systems and Computing book series (AISC, volume 1047)

\begin{abstract}
This paper presents a facility location model for improving the collection of solid waste materials. The model is especially suitable for densely populated regions with several housing units as well as encourages initial sorting of wastes. Each individual house in the collection area is designated a customer, with randomly selected customers comprising the set of candidate hubs. The fundamental feature of the model is to group the customers into clusters by assigning each customer (house) to the nearest hub. Each cluster is then assigned to exactly one waste collection site drawn from the set of potential collection locations. The objective is to minimize the total number of activated waste collection sites such that all the customers' requests are satisfied without violating the capacity limit of each site. A simple Lagrangian relaxation heuristic is developed for the problem and solved with the CPLEX solver on the AMPL platform to find a feasible solution. Results from the numerical implementation of model show the model is efficient and competitive with existing solid waste collection facility location models.
\end{abstract}

\title{
Keywords
}


Facility location problem Solid waste collection Lagrangian relaxation Lagrangian heuristic Subgradient optimization

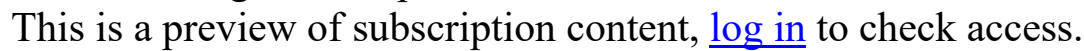

\section{Notes}

\section{Acknowledgements}

The financial support received from the Covenant University Centre for Research, Innovation and Discovery (CUCRID) for the publication of this research is hereby acknowledged. The opinions and conclusions expressed in this paper are those of the authors and not necessarily to be attributed to CUCRID.

\section{References}

1. 1 .

Adeleke, O.J.: Location-allocation-routing approach to solid waste collection and disposal. Ph.D. thesis, Covenant University, Ota (2017) Google Scholar

2. 2 .

Aydemir-Karadag, A.: A profit-oriented mathematical model for hazardous waste locating-routing problem. J. Clean. Prod. 202, 213-225 (2018) CrossRefGoogle Scholar

3. 3.

Asefi, H., Lim, S., Maghrebi, M., Shahparvari, S.: Mathematical modelling and heuristic approaches to the location-routing problem of a cost-effective integrated solid waste management. Ann. Oper. Res. 273(1-2), 75-110 (2019)MathSciNetCrossRefGoogle $\underline{\text { Scholar }}$

4. 4.

Beasley, J.E.: Lagrangean heuristics for location problems. Eur. J. Oper. Res. 65(3), 383399 (1993)rossRefGoogle Scholar

5. 5 .

Boonmee, C., Arimura, M., Asada, T.: Location and allocation optimization for integrated decisions on post-disaster waste supply chain management: on-site and off-site separation for recyclable materials. Int. J. Disaster Risk Reduction 31, 902-917 (2018)CrossRefGoogle Scholar

6. 6 . 
Chauhan, A., Singh, A.: A hybrid multi-criteria decision making method approach for selecting a sustainable location of healthcare waste disposal facility. J. Clean. Prod. 139, 1001-1010 (2016)CrossRefGoogle Scholar

7. 7.

Chen, C.H., Ting, C.J.: Combining Lagrangian heuristic and ant colony system to solve the single source capacitated facility location problem. Transp. Res. Part E-Logistics Transp. Rev. 44, 1099-1122 (2008)CrossRefGoogle Scholar

8. 8 .

Eiselt, H.A., Marianov, V.: Location modelling for municipal solid waste facilities. Comput. Oper. Res. 62, 305-315 (2015)MathSciNetCrossRefGoogle Scholar

9. 9.

Fisher, M.L.: The lagrangian relaxation method for solving integer programming problems. Manag. Sci. 50(12), 1861-1871 (2004)CrossRefGoogle Scholar

10. 10 .

Ghiani, G., Laganà, D., Manni, E., Triki, C.: Capacitated location of collection sites in an urban waste management system. Waste Manag. 32(7), 1291-1296 (2012)CrossRefGoogle Scholar

11. 11.

Ghiani, G., Manni, A., Manni, E., Toraldo, M.: The impact of an efficient col- lection sites location on the zoning phase in municipal solid waste management. Waste Manag 34(11), 1949-1956 (2014)CrossRefGoogle Scholar

12. 12 .

Hu, C., Liu, X., Lu, J.: A bi-objective two-stage robust location model for waste-toenergy facilities under uncertainty. Decis. Support Syst. 99, 37-50 (2017)CrossRefGoogle Scholar

13. 13.

Olukanni, D., Adeleke, J., Aremu, D.: A review of local factors affecting solid waste collection in Nigeria. Pollution 2(3), 339-356 (2016) Google Scholar

14. 14. 
Pissinger, D.: Algorithms for knapsack problems. Ph.D. dissertation, University of Copenhagen, Denmark (1995)Google Scholar

15. 15 .

Rabbani, M., Heidari, R., Farrokhi-Asl, H., Rahimi, N.: Using metaheuristic algorithms to solve a multi-objective industrial hazardous waste location-routing problem considering incompatible waste types. J. Clean. Prod. 170, 227-241 (2018) CrossRefGoogle Scholar

16. 16.

Rabbani, M., Heidari, R., Yazdanparast, R.: A stochastic multi-period industrial hazardous waste location-routing problem: integrating NSGA-II and Monte Carlo simulation. Eur. J. Oper. Res. 272(3), 945-961 (2019)MathSciNetCrossRefGoogle $\underline{\text { Scholar }}$

17. 17.

Rathore, P., Sarmah, S.P.: Modeling transfer station locations considering source separation of solid waste in urban centers: a case study of Bilaspur city, India. J. Clean. Prod. 211, 44-60 (2019) CrossRefGoogle Scholar

18. 18.

Wichapa, N., Khokhajaikiat, P.: Solving multi-objective facility location problem using the fuzzy analytical hierarchy process and goal programming: a case study on infectious waste disposal centers. Oper. Res. Perspect. 4, 39-48 (2017)MathSciNetCrossRefGoogle $\underline{\text { Scholar }}$

19. 19.

Yadav, V., Bhurjee, A.K., Karmakar, S., Dikshit, A.K.: A facility location model for municipal solid waste management system under uncertain environment. Sci. Total Environ. 603, 760-771 (2017)CrossRefGoogle Scholar

20. 20.

Yang, Z., Chen, H., Chu, F.: A Lagrangian relaxation approach for a large scale new variant of capacitated clustering problem. Comput. Ind. Eng. 61(2), 430-435 (2011)CrossRefGoogle Scholar

21. 21. 
Zhao, J., Huang, L., Lee, D.H., Peng, Q.: Improved approaches to the network design problem in regional hazardous waste management systems. Transp. Res. Part E: Logistics Transp. Rev. 88, 52-75 (2016) CrossRefGoogle Scholar

\section{Copyright information}

(C) Springer Nature Switzerland AG 2019

\section{About this paper}

CrossMark

Cite this paper as:

Adeleke O.J., Olukanni D.O., Olusanya M.O. (2019) An Improved Location Model for the Collection of Sorted Solid Waste in Densely Populated Urban Centres. In: Silhavy R., Silhavy P., Prokopova Z. (eds) Computational Statistics and Mathematical Modeling Methods in Intelligent Systems. CoMeSySo 2019 2019. Advances in Intelligent Systems and Computing, vol 1047. Springer, Cham

- $\quad$ First Online 20 September 2019

- DOI https://doi.org/10.1007/978-3-030-31362-3_13

- Publisher Name Springer, Cham

- $\quad$ Print ISBN 978-3-030-31361-6

- Online ISBN 978-3-030-31362-3

- eBook Packages Intelligent Technologies and Robotics Log in to check access

EUR 117.69

EUR 24.95

- Instant download

- Readable on all devices

- Own it forever

- Local sales tax included if applicable 